\title{
Integrando empresas e cooperativas de catadores em fluxos reversos de resíduos sólidos pós-consumo: 0 caso Vira-Lata
}

\author{
Interconnecting companies and waste picker cooperatives in reverse flows of post- \\ consumer solid waste: the "Vira-Lata" case
}

Jacques Demajorovic ${ }^{1}$

Elisangela Ferreira Caires ${ }^{2}$

Laudicéia Nunes da Silva Gonçalves ${ }^{3}$

Maria Janielly da Costa Silva ${ }^{4}$

\section{Resumo}

A Política Nacional de Resíduos Sólidos, aprovada em 2010, reconhece o trabalho dos catadores de materiais recicláveis, organizados como atores fundamentais da cadeia de reciclagem brasileira. Exige também que diversos setores empresariais implementem programas de logística reversa voltados a seus resíduos pós-consumo, privilegiando a integração das cooperativas de catadores nesse processo. No entanto, o pequeno interesse das empresas em gerenciar programas de logística reversa e dificuldades para integrar empresas e cooperativas desafiam a concretização desses objetivos. Esta pesquisa analisa os desafios e as perspectivas para o desenvolvimento dessas iniciativas. A estratégia de pesquisa escolhida foi a realização de um estudo de caso na Cooperativa Vira-Lata, com foco nas ações desenvolvidas pela organização com três empresas. Os resultados mostram que a integração de empresas e cooperativas tem o potencial de viabilizar fluxos reversos e gerar benefícios econômicos e socioambientais, principalmente quando há integração entre empresas, cooperativas e o poder público. Desafios como a melhoria de processos de gestão organizacional e de sistemas de informação das cooperativas, assim como dificuldades para engajar outros fornecedores da cadeia reversa, também foram identificados.

Palavras-chave: Catadores. Cooperativas. Resíduos sólidos. Logística reversa. Reciclagem.

Artigo submetido em 10 de junho de 2013 e aceito para publicação em 28 de janeiro de 2014

DOI: http://dx.doi.org/10.1590/1679-39519020

1 Doutor em Educação pela Faculdade de Educação da USP; Professor do Programa de Pós-Graduação do Centro Universitário da FEI. Endereço: Centro Universitário da FEI. Rua Tamadaré, 688, Vila Mariana, CEP 01525-000, São Paulo - SP, Brasil. E-mail: jacquesd@fei.edu.br

2 Bacharel em Administração do Centro Universitário da FEI. Endereço: Centro Universitário da FEl. Rua Tamadaré, 688, Vila Mariana, CEP 01525-000, São Paulo - SP, Brasil. E-mail: elis caires@hotmail.com

3 Bacharel em Administração do Centro Universitário da FEl. Endereço: Centro Universitário da FEl. Rua Tamadaré, 688, Vila Mariana, CEP 01525-000, São Paulo - SP, Brasil. E-mail: lausilva20@yahoo.com.br

4 Bacharel em Administração do Centro Universitário da FEl. Endereço: Centro Universitário da FEl. Rua Tamadaré, 688, Vila Mariana, CEP 01525-000, São Paulo - SP, Brasil. E-mail: janielly@trt.socicam.com.br 


\begin{abstract}
The National Policy on Solid Waste, approved in 2010, recognizes waste pickers organizations as key actors in the Brazilian recycling chain. It also requires that various business sectors deploy reverse logistics programs aimed at their post-consumer waste, favoring the interconnection of waste picker cooperatives in this process. However, little interest from companies in managing reverse logistics programs and difficulties to interconnect companies and cooperatives are major challenges to achieve these goals. This research analyzes the challenges and prospects for developing these initiatives. The research strategy chosen was conducting a case study in "Cooperativa Vira-Lata", focusing on the actions deployed by the organization along with three companies. The results show that the interconnection between companies and cooperatives has the potential to enable reverse flows and generate economic and socio environmental benefits, especially when there is an interconnection between companies, cooperatives, and the government. Challenges such as improving organizational management processes and information systems in the cooperatives, as well as difficulties to engage other suppliers within the reverse chain, were also identified.
\end{abstract}

Keywords: Waste pickers. Cooperatives. Solid waste. Reverse logistics. Recycling.

\title{
Introdução
}

A aprovação da Política Nacional de Resíduos Sólidos (PNRS), em 2010, representa um marco no Brasil ao obrigar diversos setores produtivos a implementar programas de logística reversa. Também traz uma grande inovação ao reconhecer as cooperativas de catadores como potenciais fornecedoras das empresas para a viabilização de fluxos reversos dos materiais recicláveis. Apesar do avanço representado pela legislação, há enormes desafios para a concretização desses objetivos. Em primeiro lugar, há ainda a persistente resistência do setor empresarial em implementar programas de logística reversa, mesmo quando a legislação assim o exige. Questões como custos envolvidos na atividade e o desinteresse das empresas em coordenar diretamente as atividades de coleta e destinação de seus resíduos contribuem para retardar os investimentos em programas de logística reversa (JAYARAMAN e LUO, 2007; STOCK e MULKI, 2009). Em segundo lugar, integrar as cooperativas de catadores como fornecedoras das empresas também apresenta uma série de dificuldades. Grande parte das cooperativas de catadores enfrenta a falta de infraestrutura e equipamentos que permita coletar, processar e armazenar grandes quantidades de resíduos, impossibilitando as vendas diretas para a indústria. Dessa forma, são obrigadas a realizar suas vendas para outros atores intermediários da cadeia reversa, comprometendo seus ganhos e a própria sustentabilidade de suas operações (AQUINO, CASTILHO JR. e PIRES, 2009; RIBEIRO, JACOBI, BESEN et al., 2009; SOUZA, PAULA e SOUZAPINTO, 2012).

Nesse cenário, alguns questionamentos podem ser feitos. O trabalho conjunto de empresas e cooperativas de catadores no cenário brasileiro poderia contribuir para contornar alguns dos principais desafios apresentados na literatura para a expansão da logística reversa? Quais condições possibilitariam às cooperativas serem fornecedoras de serviços nos fluxos reversos das empresas? Quais seriam os benefícios gerados para a cooperativa ao se associarem às empresas nos fluxos reversos?

É importante frisar que ao discutirem a relação logística reversa, empresas e cooperativas apresentam o desafio da lacuna das literaturas nacional e internacional nesta temática. A maior parte dos estudos sobre logística reversa tem como foco a experiência dos países desenvolvidos com uma realidade muito distinta dos países em desenvolvimento (LAU e WANG, 2009). Nestes últimos, é preciso considerar que já existe uma cadeia de reciclagem, onde atuam organizações formais, informais e catadores independentes movimentado volumes crescentes de resíduos de volta para o processo produtivo (LUNDGREEN, 2012). A realidade brasileira exemplifica bem essa situação, pois os índices de reciclagem no Brasil para diversos materiais equiparam-se ou mesmo superam os valores registrados nos EUA, países da União Europeia e da América Latina. Dados do Compromisso Empresarial para Reciclagem(CEMPRE, 2010) mostram que o 
Brasil, em 2008, ocupava a liderança na reciclagem de latas de alumínio com 91,5\%. É também um dos líderes na coleta de PET, pois o índice de recuperação $(54,2 \%)$ fica atrás somente do Japão $(69,2 \%)$.

Embora esta expansão possa ser creditada a vários fatores, tais como, o desenvolvimento industrial do país, a aceleração da urbanização e a maior conscientização da população brasileira pela temática socioambiental, inúmeros autores destacam o trabalho realizado por milhares de catadores como o principal responsável pelo sucesso do mercado de reciclagem no país (GRINBERG, 2004; EIGENHAUER, FERREIRA, e ADLER, 2005; RIBEIRO, JACOBI, BESEN et al., 2009). Para esses autores, a viabilidade da cadeia de reciclagem é sustentada por um modelo que se apoia na exploração do trabalho realizado pelos catadores, já que os valores pagos pelo material coletado são extremamente baixos. Um quadro semelhante pode ser observado em outros países, conforme Lundgreen (2012). Para o autor, a expansão da reciclagem em países como a China e a Índia acontece em função da precarização do trabalho de catadores informais. Nesse cenário, diversos autores defendem que os modelos de logística reversa nos países em desenvolvimento promovam a integração entre vários setores, incluindo as empresas, o setor público e as organizações não governamentais (LAU e WANG, 2009; LUNDGREN, 2012). Este trabalho colaborativo seria uma alternativa para expandir a logística reversa, além de melhorar as condições de trabalho dos catadores, especialmente quando realizam suas atividades por meio de cooperativas. De forma a contribuir nesse debate, tendo como base os objetivos da PNRS apresentados, optou-se pela realização de um estudo de caso em uma cooperativa de catadores atuando em São Paulo, que integra o programa de coleta seletiva municipal e que conseguiu inserir-se como fornecedora nos fluxos reversos de três empresas.

\section{Logística Reversa e a Cadeia de Reciclagem no Brasil}

Inúmeros artigos publicados enfatizam a persistente resistência das empresas em implementar programas de logística reversa, mesmo considerando o avanço do conhecimento relacionando o descarte incorreto de resíduos pós-consumo com o aumento de impactos sobre a saúde humana e o meio ambiente (ROGERS e TIBBEN-LEMBKE, 1998; GUNGOR e GUPTA 1999; FLEISCHMANN, KRIKKE, DEKKER et al., 2000). Diversas são as razões para esta realidade que podem ser buscadas tanto em trabalhos precursores no tema, assim como nos mais recentes. Para Thierry, Salomon, Nunem et al. (1995),o foco dos fabricantes é melhorar o desempenho nos processos de fabricação, venda e distribuição, desconsiderando a destinação dada pelos clientes aos produtos ao final de sua vida útil. Essas práticas podem ser explicadas pelas crenças dos gestores de que os custos envolvidos com a reciclagem são maiores do que os benefícios econômicos obtidos com esse processo. Para Stock e Mulki (2009), isto explicaria o fato das empresas postergarem a implantação de programas de logística reversa. Já Jayaraman e Luo (2007) defendem que, ainda que muitas empresas pensem em viabilizar os fluxos reversos, o mesmo não se pode dizer sobre seu interesse em estruturar e coordenar diretamente esse processo. Como sustentam Demajorovic, Zuñiga, Boueres et al. (2012), a necessidade de desenvolver uma infraestrutura para coletar resíduos pós-consumo e identificar alternativas para assegurar a reutilização do material ou destinar de forma segura os resíduos são atividades estranhas para a maior parte das empresas. Assim, no momento de avaliar e implementar um programa de logística reversa, os desafios se apresentam de forma mais evidente do que as oportunidades, como, por exemplo, antecipar a legislação (STOCK e MULKI, 2009); os benefícios para a imagem da empresa (RAVI, SHANKAR e TIWARI, 2008), oportunidades de redução de custos e ganhos de competividade com redesenho de produtos e processos (JAYARAMAN e LUO, 2007; DEMAJOROVIC e MATURANA, 2009).

Nesse contexto, ainda que os consumidores sejam hoje reconhecidos como importantes indutores da modificação do comportamento das empresas, ao que se refere à destinação correta dos resíduos pósconsumo (JANSE, SCHUUR e BRITO, 2009), o desenvolvimento da legislação nos países desenvolvidos, obrigando as empresas fabricantes e importadores a implementarem programas de logística reversa, é considerado como o principal impulsionador para a ampliação das iniciativas (LAU e WANG, 2009). O 
mesmo autor sustenta que uma estratégia para diminuir a resistência do setor empresarial, em implementar a logística reversa nos países em desenvolvimento, é a sua integração com o setor público e não governamental.

No Brasil, um grande avanço nessa direção foi a aprovação da PNRS, instituída pela Lei $\mathrm{n}^{\circ}$ 12.305/2010, definindo um regime de responsabilidade compartilhada sobre o ciclo de vida de diversos produtos. Reveilleau (2011, p. 164) destaca a importância dessa iniciativa ao registrar que a PNRS superou "um dos obstáculos que era a inexistência de uma norma de âmbito nacional que tivesse como foco principal gerenciar os resíduos, atribuir responsabilidades aos seus geradores, aos consumidores e ao poder público". Especialmente importante foi a inclusão no artigo XII da Lei da Obrigatoriedade de diversos setores empresariais para implementarem seus programas de logística reversa até 2014. A PNRS também reconhece as cooperativas de catadores de materiais recicláveis como agentes fundamentais na cadeia de reciclagem. Para Pereira e Teixeira (2011), a inclusão das cooperativas na PNRS foi precedida por uma série de medidas adotadas durante o Governo Lula (2003-2010) beneficiando os catadores. Destaca-se a expansão de recursos disponibilizados pelas instituições, tais como, BNDES, Petrobras e Fundação Banco do Brasil, para investimentos em infraestrutura e capacitação das cooperativas de catadores e associações. Nesse contexto, a PNRS vai além da simples valorização do trabalho desempenhado pelos catadores, recomendando a priorização de parcerias entre empresas e os catadores organizados para a implementação das iniciativas de logística reversa nas empresas.

O trabalho desenvolvido por Aquino, Castilho Jr. e Pires (2009) mostra a cadeia de reciclagem pós-consumo dividida em cinco níveis, conforme a figura a seguir.

Figura 1

\section{Cadeia de reciclagem}

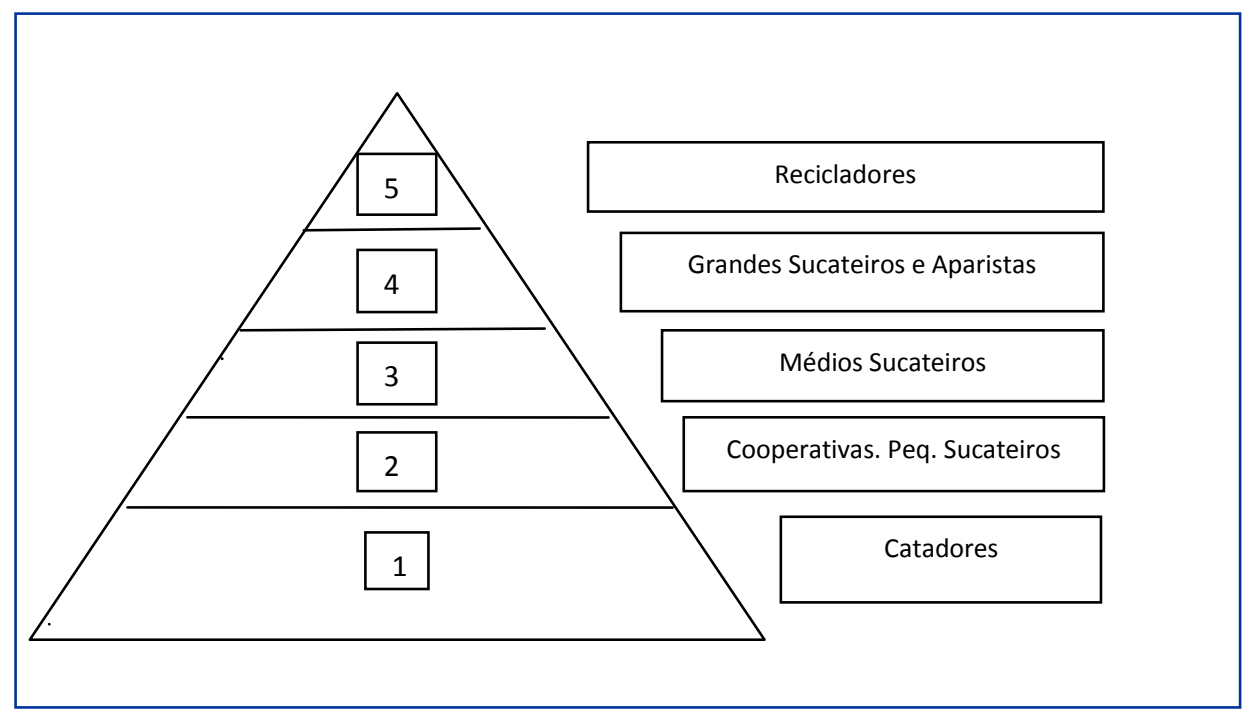

Fonte: Elaborado pelos autores a partir de Aquino, Castilho Jr. e Pires (2009)

Na base, estão os catadores autônomos que coletam materiais recicláveis pelas ruas ou casas e que vendem esse material para as organizações intermediárias. Já as organizações intermediárias são as que realizam atividades de prensagem, armazenagem e transporte. Encontram-se divididas em três níveis devido às características das organizações, como tamanho e forma de comercialização. Assim, no segundo nível, encontram-se as cooperativas de catadores, como os pequenos sucateiros, trabalhando muitas vezes na 
informalidade. Recebem ou compram os materiais de catadores e vendem esse material para níveis intermediários superiores e, em alguns casos, diretamente para uma empresa recicladora. No terceiro nível, aparecem as organizações intermediárias com maior capacidade de processamento de material e estocagem, vendem tanto para outros intermediários como para mais de uma empresa recicladora. Já no quarto nível, encontram-se grandes sucateiros e aparistas que processam, no mínimo, 100 toneladas por mês de material reciclável e vendem exclusivamente para as empresas recicladoras. No último nível, estão as empresas recicladoras que fazem a transformação do material reciclável e vendem diretamente para a indústria.

Esta forma de estruturação da cadeia produtiva reversa de pós-consumo contribui para os problemas de distribuição desigual do valor gerado na atividade, impactando especialmente os catadores e as cooperativas, $\mathrm{e}$, ao mesmo tempo, viabiliza financeiramente a cadeia de reciclagem (EINGENHAUER, FERREIRA, e ADLER, 2006).Para os catadores autônomos, a única opção é vender isoladamente aos pequenos sucateiros, sem qualquer condição de barganha. Assim, recebem a menor parcela do que é gerado do valor na cadeia de reciclagem, apesar de contribuir com a maior parcela do que é coletado. Grimberg et al. (2004) afirmam que os intermediários na cadeia conseguem obter uma margem de $100 \%$ entre seu preço de venda e o que paga para o catador. Porém, como afirma Gonçalves-Dias (2009), esta diferença não onera a cadeia de reciclagem, já que o valor muito baixo recebido pelos catadores permite manter o preço do material reciclável competitivo até chegar ao nível mais elevado da cadeia. Lundgreen (2012) defende que isto é uma realidade nos diversos países em desenvolvimento e que caso o trabalho desses catadores respeitasse as normas de segurança e ambientais, as atividades de coleta e separação dos materiais seriam financeiramente inviáveis.

No Brasil, o Movimento Nacional de Catadores, articulado com outros setores da sociedade, tem atuado intensamente para a reversão deste quadro. Fundado em 2001, conta hoje com mais de 80 mil associados, constituindo-se no maior movimento de recicladores do mundo (IJGOSSE, 2009). Sua mobilização contribuiu para a criação da categoria de catadores de materiais recicláveis no Ministério do Trabalho em 2002. O movimento defende também, assim como diversos especialistas, o estímulo do trabalho dos catadores em cooperativas de forma a ampliar a coleta seletiva, assegurar um trabalho digno e melhorar a distribuição de renda (JACOBI e BESEN, 2011; MNCR, 2012, SOUZA, PAULA e SOUZA-PINTO, 2012). Espera-se que estas organizações, dotadas de infraestrutura adequada e equipamentos, consigam aumentar a eficiência do processo, resultando em vendas crescentes de materiais recicláveis, inclusive para as indústrias (AQUINO, CASTILHO JR. e PIRES, 2009). Um dos principais benefícios de vender diretamente para a indústria está na expansão significativa dos valores recebidos pelos materiais recicláveis. O mesmo estudo de Aquino, Castilho Jr. e Pires (2009), em Florianópolis, mostra a grande variação de preços praticados na cadeia de reciclagem. No caso do papel ondulado, enquanto as cooperativas recebiam cerca de $\mathrm{R} \$ 0,10 / \mathrm{kg}$ das organizações intermediárias, as recicladoras pagavam $\mathrm{R} \$ 0,20 / \mathrm{kg}$ para as empresas intermediárias do nível 3. No caso do polietileno de alta densidade, as cooperativas recebiam $\mathrm{R} \$ 0,25 / \mathrm{kg}$, enquanto as recicladoras pagavam $\mathrm{R} \$ 1,20 / \mathrm{kg}$ para as empresas intermediárias. Já a pesquisa de Jesus e Barbieri (2013) defende que quando as cooperativas conseguem vender vidro diretamente para as empresas recicladoras, sem passar por intermediários, o preço recebido pode ser 40 a $60 \%$ maior. Além dos ganhos financeiros, a pesquisa de Jesus e Barbieri (2013), com quatro cooperativas atuando em São Paulo, que conseguiram ser incluídas como prestadoras de serviços em fluxos reversos empresariais, mostra outras vantagens da relação direta entre as organizações de catadores e as indústrias. Destacam os ganhos de escala, o incentivo à regularização e o estimulo à aprendizagem em atividades como pré-processamento,de forma a se adequar aos padrões de qualidade exigidos pelas empresas em relação aos seus fornecedores.

Apesar da expansão de programas municipais de apoio às cooperativas, grande parte dessas organizações carece da estrutura necessária para comercializar diretamente com a indústria, sendo obrigadas a vender para organizações intermediárias da cadeia, comprometendo seus ganhos. Ribeiro, Jacobi, Besen et al. (2009) destacam,em sua pesquisa realizada com 32 cooperativas em 12 municípios da região metropolitana,como principais desafios enfrentados pelas cooperativas para a venda direta às indústrias, os problemas organizacionais e de infraestrutura, incluindo relações pessoais e deficiências de gestão, a reduzida quantidade de material reciclável em função da concorrência com catadores autônomos e sucateiros, e a falta 
de veículos. Os autores também enfatizam a não efetivação da remuneração dos serviços prestados pelas cooperativas. Poucos são os municípios que remuneram os serviços dos catadores como agentes de coleta, como, por exemplo, em Londrina. Já o estudo de Besen e Ribeiro ( 2010), que desenvolveu indicadores para avaliar a sustentabilidade das cooperativas de catadores, destacou o processo de regularização, capacitação dos membros, renda mensal auferida, efetiva participação dos membros, uso de equipamentos de proteção individual e parcerias como elementos essenciais para o melhor funcionamento dessas organizações. Especificamente no que se refere ao último indicador, as parcerias incluem os acordos estabelecidos pelas cooperativas com diferentes tipos de organizações, incluindo o poder público, organizações não governamentais e empresas.

No cenário apresentado, argumenta-se que as empresas podem impactar positivamente o trabalho das cooperativas. Como se tratam de grandes geradores e compradores de resíduos,podem, ao estabelecer acordos com as cooperativas, contribuir significativamente para o aumento da receita dessas organizações. Mas para que isso se torne realidade, as empresas precisam estar dispostas a desenvolver parcerias com as organizações. Carvalho e Barbieri (2010) enfatizam a integração como elemento essencial para o adequado funcionamento da cadeia de suprimentos.Considerando que a maior parte dos resíduos pós-consumo inicia seu fluxo reverso pelas mãos dos catadores, a integração entre esses atores e empresas torna-se fundamental para aumentar a qualidade e a quantidade deste processo. No entanto, como afirma Motta (2005), essas parcerias só podem ser viabilizadas na medida em que os catadores se encontrem organizados na forma de cooperativas ou associações. Além disso, Gonçalves-Dias (2009) defende que as empresas necessitam desenvolver novos arranjos interorganizacionais que incluam as cooperativas no fluxo reverso de resíduos. Dados do Instituto Ethos (2007), em pesquisa realizada com a Fundação Avina, mostram algumas iniciativas nesse sentido. A empresa Belgo Mineira fechou um acordo com a Associação dos Catadores de Papel, Papelão e Material Reciclável (Asmare) de Belo Horizonte, que contempla a cessão de espaço na própria empresa, onde catadores ligados à Asmare fazem a separação dos materiais recicláveis doados, sendo encaminhados para a cooperativa para serem comercializados. A empresa também remunera os serviços de coleta feito pela organização por meio de acordo comercial. No entanto, a própria pesquisa mostra que o desenvolvimento da relação empresa e cooperativa é complexo e enfrenta uma série de entraves para sua concretização. As empresas conhecem muito pouco a realidade dos catadores, limitando suas poucas interações nas cooperativas às ações assistencialistas, como doação de material ou equipamentos. Também, como afirma Gonçalves-Dias (2009), o sistema de compra promovido pelas grandes indústrias recicladoras tem uma dinâmica que dificulta a inserção das cooperativas, na medida em que valoriza fornecedores que possam entregar grandes volumes com alta qualidade (materiais limpos, prensados e enfardados), além da regularidade da entrega. Dessa forma, a autora reforça a assimetria de poder entre os dois tipos de organizações. As grandes recicladoras ditam as regras, definem tecnologias e são beneficiadas pelo sistema jurídico e legal, cabendo às cooperativas, o papel secundário de mero fornecedor de mão de obra e serviços. Também a pesquisa de Jesus e Barbieri (2013) identificou diversos desafios para a integração de cooperativas nos processos de logística reversa empresarial, tais como, conflitos entre os prazos de pagamento ditados pelas empresas pelo material reciclável e o de remuneração dos cooperados. Os autores destacam também as dificuldades das cooperativas em desenvolver fornecedores, exemplificando por meio do caso da cadeia reversa de plástico. As empresas de bens de consumo, organizações locais das cadeias de plásticos, pouco contribuem para integrar as cooperativas aos outros atores da cadeia, dificultando a expansão da coleta de material reciclável processado pelos catadores e o aumento das vendas diretamente para as recicladoras. Por fim, há uma fragilidade do discurso de responsabilidade ambiental das empresas e sua relação colaborativa com as cooperativas que ficam patentes em épocas de crise econômica. Para o MNCR (2012), nesses períodos, as empresas optam pela compra de matérias-primas virgens em função da queda do preço em detrimento dos materiais recicláveis. O contexto apresentado mostra que a efetivação da legislação enfrenta uma série de desafios, tanto ao que se refere ao interesse pela logística reversa por parte das empresas, como a integração dessas organizações com as cooperativas. Argumenta-se que, ainda que a concretização dessas parcerias seja bastante complexa, considerando as diferentes realidades das empresas e 
das cooperativas, a aproximação desses dois atores abre novas possibilidades de relações, contribuindo para superar alguns dos desafios presentes na implantação de fluxos reversos de materiais pós-consumo.

\section{Procedimentos Metodológicos}

A estratégia de pesquisa escolhida para esta pesquisa foi a realização de um estudo de caso único. Eisenhardt (1989) e Gil (1991) argumentam que este método de pesquisa é recomendável em casos de pesquisas exploratórias e quando o objeto de estudo apresenta um caráter exemplar. É exatamente o caso desta pesquisa, pois são limitados os trabalhos abordando o tema da logística reversa, envolvendo a relação de cooperativas com empresas privadas. A seleção do caso se deu a partir de informações prévias levantadas que revelaram a exemplaridade da iniciativa. Ressalva-se que um dos autores trabalha com pesquisas em cooperativas de catadores há mais de 15 anos e ao entrar em contato com a Cooperativa Vira-Lata, identificou algumas características únicas da organização em relação à sua participação nos fluxos reversos de empresas. A cooperativa coleta sucata de ferro nas oficinas da Porto Seguro e comercializa o material com a Gerdau. Também realiza a coleta de embalagens de vidro dos produtos da Empresa Diageo, reecaminhando-os para empresas recicladoras para a produção de novas garrafas reutilizadas pela própria empresa. Para Yin (2005), é fundamental na realização de um estudo de caso a utilização de diversas fontes de evidências, pois possibilitam checar a validade e a confiabilidade das informações por meio da comparação dos dados levantados com diferentes fontes de informação. A coleta de dados incluiu a realização de entrevistas semiestruturadas, análise de documentos e observação. Nas entrevistas, as questões abordaram o histórico da cooperativa, a importância das parcerias com os setores público e privado, os desafios na relação com as empresas e os benefícios gerados para a cooperativa ao trabalhar diretamente com as empresas. Com relação aos documentos, obteve-se acesso a todo o banco de dados da cooperativa, no que se refere à quantidade coletada, receita gerada e seu balanço ecológico. Já a observação feita em sucessivas visitas durante o período da pesquisa possibilitou verificar os processos de trabalho e organizacionais,e como foram sendo modificados ao longo do tempo. Destaca-se que o período da pesquisa foi de 2008 a 2011 . De forma a enriquecer a análise do caso, buscou-se também saber a percepção das empresas privadas participantes dos projetos, sendo realizadas também entrevistas com gerentes das áreas de sustentabilidade e produção. Nesse caso, as questões envolviam os fatores motivadores para trabalhar com cooperativas, os desafios para implementar a logística reversa e os benefícios da cooperação. Também uma entrevista foi realizada com um representante da Prefeitura de São Paulo, que coordena o programa de coleta seletiva com as cooperativas. No total, 10 entrevistas foram realizadas, gravadas e transcritas, sendo quatro com representantes da cooperativa, cinco das empresas e uma da Prefeitura. O tratamento dos dados concentrouse na análise em profundidade dos dados obtidos na cooperativa e nas empresas, a partir da triangulação dos dados levantados por meio das entrevistas, da observação direta e de análise dos documentos, que são apresentados a seguir.

\section{Resultados da Pesquisa de Campo}

A cooperativa de catadores do Projeto Vira-Lata iniciou suas atividades no ano de 1998. Seu objetivo era gerar renda para a comunidade por meio da coleta e da venda de materiais recicláveis. Em 1999, seus 11 integrantes coletaram 57 toneladas, gerando uma receita de $\mathrm{R} \$ 8.000$. Em 2000, a organização amplia a coleta de materiais recicláveis por meio de acordos com condomínios residenciais.

Um dos grandes desafios enfrentados pela cooperativa era justamente a venda direta para a indústria. Seus representantes afirmam que uma empresa recicladora de papel só comprará se puder levar um caminhão de 14 toneladas, acompanhado de nota fiscal. Somente com a formalização da cooperativa foi possível ampliar a 
coleta e o processamento de material por meio de diversas parcerias feitas com o poder público e empresas privadas.

A compra de novos equipamentos, como prensas e veículos, foi assegurada com recursos da Petrobras e do Banco do Brasil. Além disso, empresas, como a Rede Globo e a Associação Comercial de São Paulo, passaram a doar seus materiais, alguns de alta qualidade e maior valor agregado, como, por exemplo, o papel branco separado. Em 2008, os 120 cooperados coletaram mais de duas mil toneladas, gerando uma receita de R \$ 739.000,00 a partir da venda de plástico, papel, papelão, jornal, revista, vidros, sucatas e acrílico. No total, o projeto Vira-Lata processa entre 48 e 60 tipos de materiais diferentes.

Os anos de 2009 e 2010 foram bastante difíceis para a cooperativa, pois a crise financeira mundial trouxe reflexos muito negativos para o mercado de reciclagem brasileiro, reduzindo significativamente os preços pagos pelo material reciclável. Em 2009, o valor recebido por quilo do PET, em relação a 2008, reduziu-se em 25\%, enquanto latinhas e revistas registraram uma redução de $43 \%$ e $66 \%$, respectivamente. Como resultado, a diminuição do ganho dos cooperados foi expressiva, passando de $\mathrm{R} \$ 1.200,00$ para $\mathrm{R} \$ 400,00$ mensais, e o número de cooperados reduziu de 120 para apenas 30.

A queda dos preços também afetou a capacidade de coleta da cooperativa, agravando o problema, pois dos quatro caminhões utilizados até o período anterior à crise, sobraram apenas dois. As tabelas abaixo mostram a evolução do total de material coletado e a receita no período.

Gráfico 1

\section{Evolução do volume total coletado de resíduos do Projeto Vira-Lata}

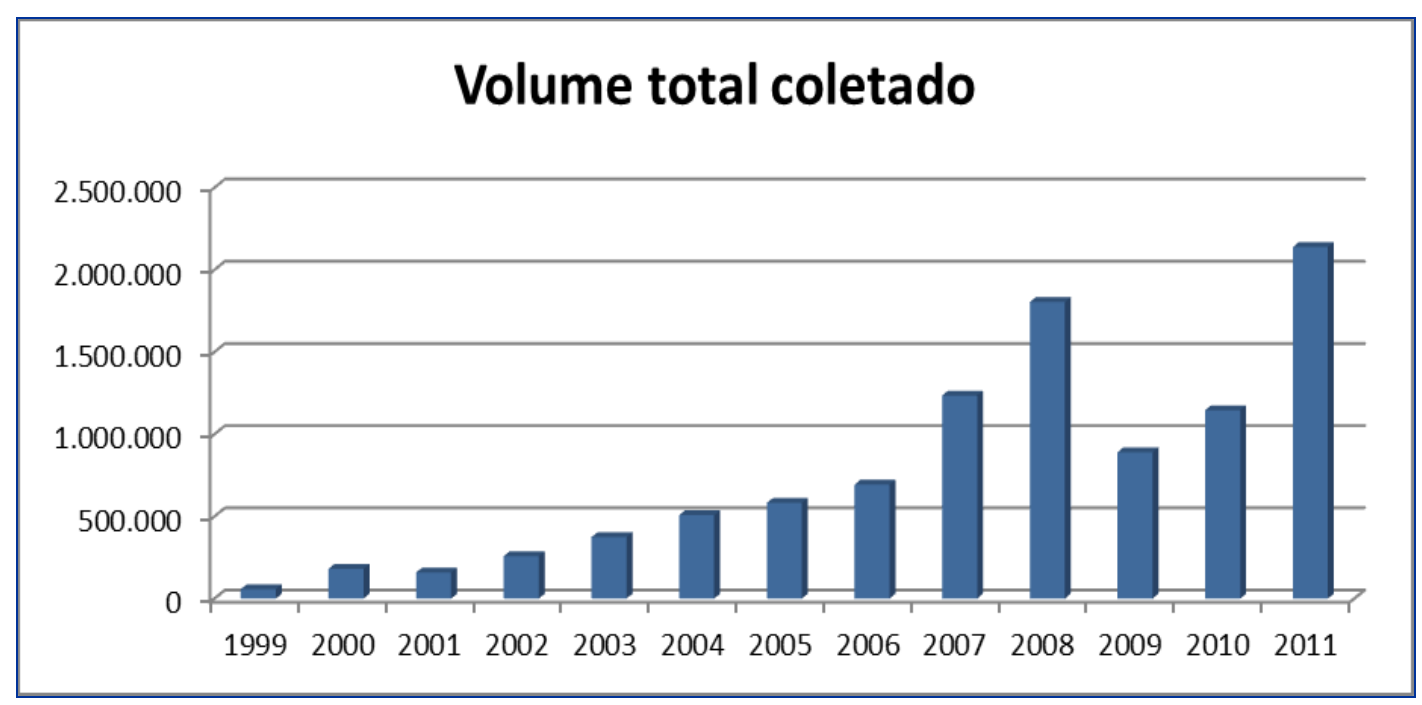

Fonte: Elaborado pelos autores (2012) 
Gráfico 2

Evolução da receita do projeto

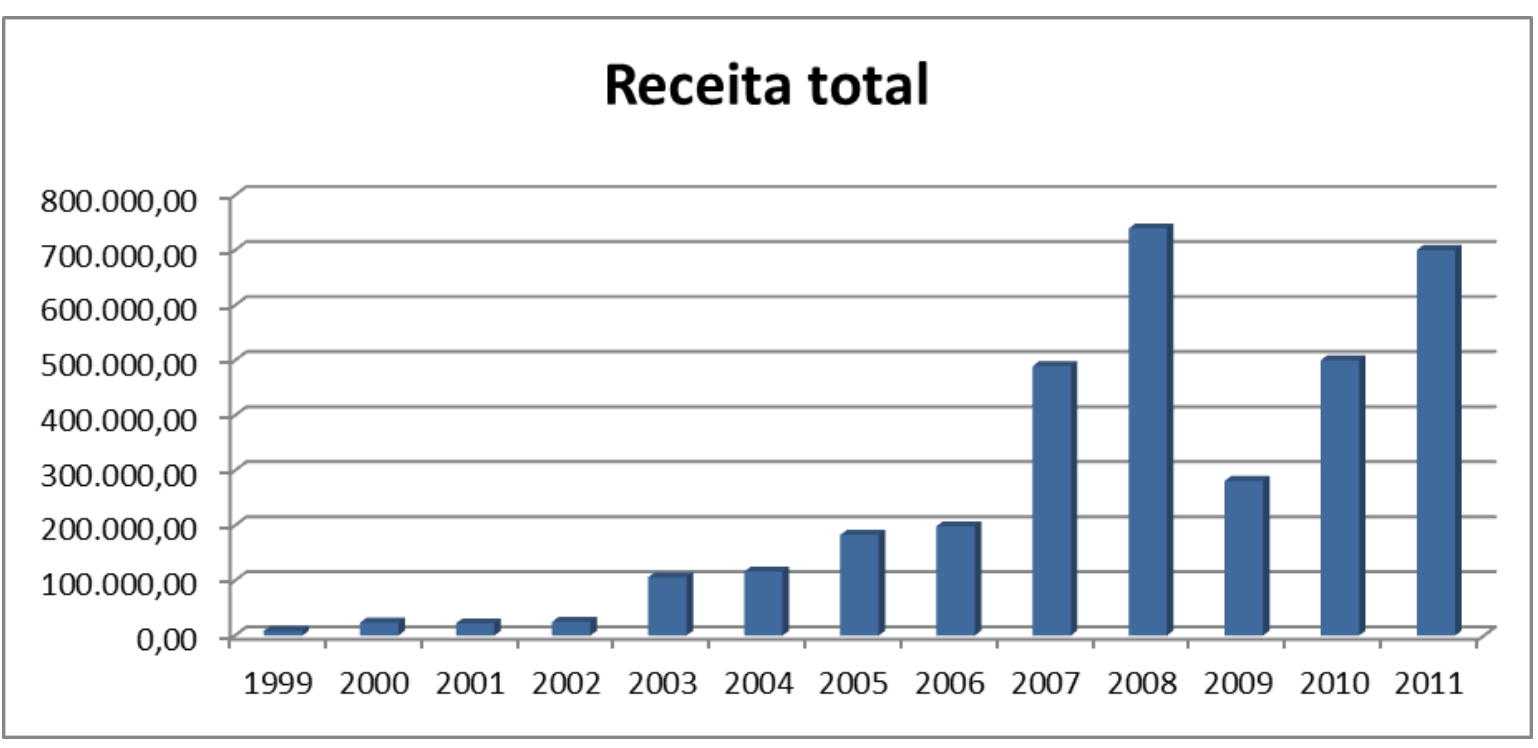

Fonte: Elaborados pelos autores (2012)

Os dados mostram que em 2008, atinge-se o ápice com um volume de $2.024 .688 \mathrm{~kg}$ e uma receita de $\mathrm{R} \$$ 739.339,23. Em 2009, o total coletado diminui para $1.035 .217 \mathrm{~kg}$, representando uma redução de $48 \%$. Maior ainda foi a redução percentual da receita, que chegou a $\mathrm{R} \$ 280.863,17$, diminuindo em $62 \%$. Em 2010, inicia-se uma recuperação, tanto no volume como na receita, embora ainda em valores menores que os de 2008. Nesse ano, foram coletados $1.358 .613 \mathrm{~kg}$, representando um aumento de $31 \%$ e a receita atingiu $\mathrm{R} \$$ 500.086. Já em 2011, a cooperativa conseguiu recuperar-se, ultrapassando o valor de 2008, com 2.138.254 $\mathrm{kg}$, embora a receita ainda apresentasse uma pequena redução de 5,6\%.

Os números apresentados mostram a grande vulnerabilidade das cooperativas em momentos de crise. Além da redução do volume de material coletado e vendido, observa-se uma queda dos preços proporcionalmente ainda maior, afetando a receita total e a renda dos cooperados. Esta característica do mercado explica, segundo representantes da Vira-Lata, porque tantas cooperativas tiveram que encerrar suas operações nos anos de 2009 e 2010. Este não foi o caso da Vira-Lata. Isto pode ser explicado por dois fatores principais; além das parcerias com a Prefeitura de São Paulo e a Fundação Banco do Brasil, garantindo novos equipamentos e um novo galpão, a organização ampliou contratos com diversas empresas do setor privado para o recebimento e a venda de materiais recicláveis, como exemplos, a Editora Globo, Gerdau, Porto Seguro, Suzano Papel e Celulose, Diageo, Petrobras, Rede Ferroviária Federal S.A, Indústria CISPER Produção de vidros e Ambev Entre essas parcerias,destaca-se a seguir duas delas que já integram a cooperativa como fornecedora em seus fluxos reversos.

\section{A Porto Seguro e a Gerdau}

A Gerdau iniciou suas atividades como uma fábrica de pregos no ano de 1901, expandindo-se para o ramo siderúrgico. Hoje, conta com 37 mil colaboradores, distribuídos em 13 países. Ocupa uma posição destacada no mercado mundial de produção de aço, sendo uma das empresas mais internacionalizadas da economia brasileira. Em 2010, sua receita atingiu R \$ 35,7 bilhões (GERDAU, 2012). O aço produzido pela empresa é 
empregado em diversos setores, tais como, construção civil, automobilístico e eletrodomésticos. Em seu processo produtivo, $70 \%$ de sua matéria-prima provém de material reciclável -a sucata ferrosa.

A Porto Seguro, por sua vez, iniciou suas atividades em 1945,tendo como principal foco de atuação o mercado de seguros de automóveis. Hoje, é uma empresa que atua oferecendo várias modalidades de seguro, incluindo automóvel, saúde, patrimônio, vida e transportes. É líder no segmento de seguro de automóveis, representando $32,4 \%$ do mercado paulista e $20 \%$ do mercado nacional. Conta com 115 sucursais e regionais espalhadas pelo território nacional que empregam diretamente cerca de 7.600 funcionários e mais de 8 mil prestadores de serviços. Em 2010, sua receita total foi de R 9.2 bilhões (PORTO SEGURO, 2011).

\section{Construindo o fluxo reverso}

A Gerdau compra a maior parte de sua matéria-prima no mercado secundário de sucata, tendo como principal fornecedor os sucateiros. Em 2003, desenvolveu uma iniciativa nas cooperativas de catadores, conciliando a necessidade de adquirir sucata com um projeto de responsabilidade socioambiental. Segundo representantes da Gerdau, a ideia surgiu a partir de sua participação no CEMPRE, com o contato com outras empresas que já trabalhavam em parcerias com as cooperativas.

O projeto da Gerdau tem como área prioritária os 11 municípios em que possui unidade de produção. A ação da empresa visa apoiar as cooperativas que já estão em funcionamento ou contribuir para a implantação de uma nova cooperativa a partir do tripé da sustentabilidade: promove a inclusão de catadores (dimensão social), estimula a reciclagem (dimensão ambiental) e atende às necessidades da empresa em assegurar maior quantidade de matéria-prima (dimensão econômica).

O projeto Vira-Lata foi selecionado como parceiro em 2005, recebendo a cessão em comodato de um triturador e uma caçamba para o armazenamento de sucata. Também foram realizados cursos de capacitação na área de segurança de trabalho, enfatizando o uso adequado de Equipamentos de Proteção Individual (EPI) e a correta segregação dos vários tipos de sucata.

Hoje, a Gerdau compra toda a sucata ferrosa coletada pela cooperativa, incluindo as latas coletadas nos condomínios e postos de coleta seletiva dos supermercados. Em pouco tempo, esta iniciativa promoveu um grande aumento do volume de sucata processada pela cooperativa e gerou um aumento substancial da receita com a venda desse material. Dados do Projeto Vira-Lata mostram que, em 2005, o volume de sucata coletado foi de uma tonelada e a receita de $\mathrm{R} \$ 837,00$. Em 2007, o volume cresceu para mais de 80 toneladas e a receita superou $\mathrm{R} \$ 29.000,00$.

Os bons resultados alcançados serão potencializados com a entrada da Porto Seguro neste fluxo em 2008. A partir de um projeto de coleta seletiva de material de escritório doado à Vira-Lata, a empresa passou a se concentrar no destino da sucata ferrosa de suas 180 oficinas em São Paulo conveniadas e mais 35 operadas diretamente. Até aquele momento, as oficinas tinham autonomia para vender materiais como para-lamas, amortecedores e portas de automóveis, muito valorizados no mercado secundário. Assim, a Porto temia que as peças pudessem ter como destino o mercado de peças de automóvel. A busca por uma solução deste problema, condizente com sua política de responsabilidade socioambiental, esbarrava na falta de conhecimento da empresa sobre o mercado de sucata.

Nesse contexto, a Vira-Lata foi fundamental, pois serviu como elo entre as duas empresas que viram oportunidades antes desconhecidas. Se para a Porto Seguro, a presença da Gerdau era a garantia de uma destinação adequada e segura da sucata gerada nas oficinas, para a Gerdau era a certeza de receber um material de alto valor agregado em grande quantidade para sua produção de aço.

O problema era que as empresas não tinham estrutura para fazer a coleta e não se interessavam em montar uma logística específica para viabilizar as atividades de transporte e separação do material. Nesse quadro, o 
Projeto Vira-Lata viabilizou este fluxo reverso ao garantir o transporte, a separação e o armazenamento do material.

A evolução da sucata ferrosa na composição da receita da cooperativa mostra a relevância deste arranjo. As 30 toneladas comercializadas renderam $\mathrm{R} \$ 7$ mil, contribuindo com cerca de $3 \%$ da receita anual da cooperativa. Já as 220 toneladas coletadas em 2008 geraram R \$ 87 mil, equivalentes a $11 \%$ da receita anual. Essa parceria acabou desempenhando um papel muito importante durante a crise vivida pela cooperativa em 2009, ainda que o volume processado de sucata de ferro também tenha sido afetado pela crise econômica mundial, conforme pode ser visto na tabela abaixo:

Gráfico 3

Volume coletado de sucata de ferro do Projeto Vira-Lata

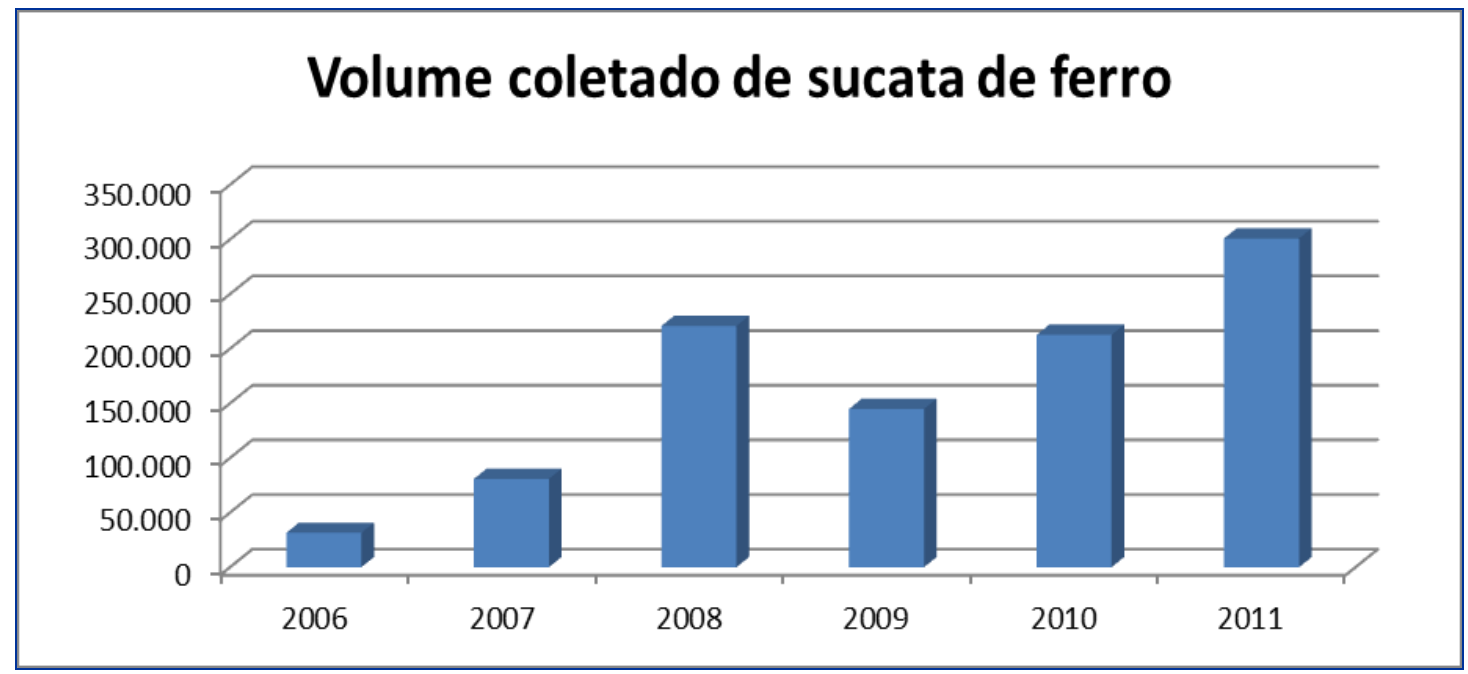

Fonte: Elaborado pelos autores (2012).

Gráfico 4

Receita gerada com a coleta de sucata

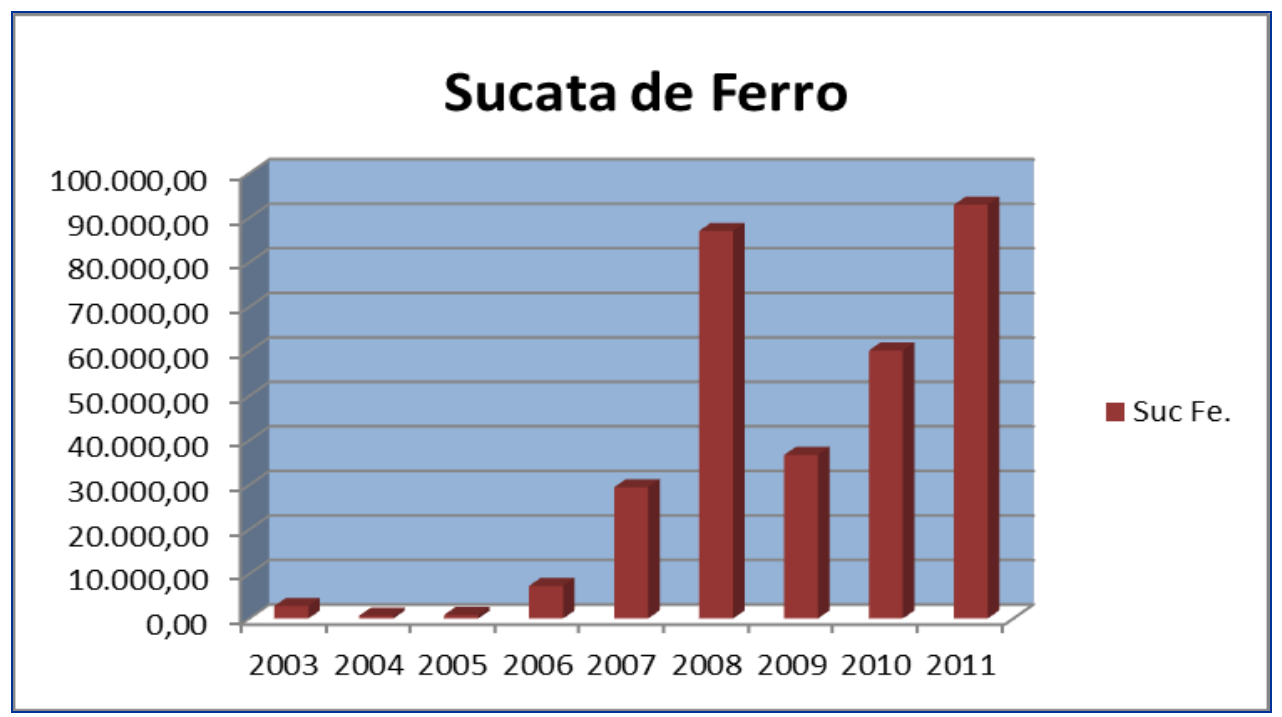

Fonte: Elaborado pelos autores. 
Em 2009, houve uma redução de 34\% do total coletado, chegando a 145 toneladas. Em 2010, é significativo que a cooperativa tenha conseguido coletar quase a mesma quantidade de 2008, alcançando 213 toneladas, sendo 84\% doados pela Porto Seguro. Em 2011, registrou-se novo aumento, alcançando cerca de 300 toneladas, superando o total coletado em 2008. Já a receita obtida subiu de cerca de $R \$ 60.000$ para 92.000 em relação ao ano anterior. Já a contribuição da sucata ferrosa para o total da receita da cooperativa chegou a $13 \%$.

Para os representantes da cooperativa, também foi importante o relativo equilíbrio dos preços com a venda da sucata ferrosa. Conforme comentado, enquanto materiais como PET recuaram cerca de $65 \%$ nos anos da crise, a sucata vendida diretamente para a Gerdau registrou uma redução de $11 \%$ no mesmo período.

\section{A Diageo}

A Diageo é a maior empresa do setor de bebidas alcoólicas do mundo, comercializando várias categoriais de bebidas, incluindo cerveja, vinho e uísque. Atua em mais de 180 países, empregando 20 mil pessoas e detém marcas famosas, tais como, Johnny Walker e Guinness. Nos últimos anos, as economias emergentes da Ásia, América Latina e África têm sido o principal vetor de expansão da empresa. Em 2005, essas regiões representavam $22 \%$ da receita do grupo, mas as projeções sinalizam que esses mercados representarão50\% do total em 2015. O maior impacto ambiental de seu negócio está na grande geração de embalagens de vidros pós-consumo que podem permanecer por longo tempo em aterros ou lixões. No entanto,para seus representantes,o vidro, ao contrário da maioria das embalagens, pode ser $100 \%$ reaproveitável. Quando reutilizado como matéria-prima para fabricar uma garrafa igual, atendendo uma mesma finalidade, reduz-se significativamente seu impacto ambiental.

Quando a empresa cogitou implantar a logística reversa com seus distribuidores, primeiramente pensou que o modelo de coleta do material poderia ser integrado à distribuição. O mesmo caminhão que entregasse as bebidas levaria os cascos vazios, otimizando os custos. Esta alternativa, porém, mostrou-se inviável, pois a quantidade de garrafas vazias acumuladas nos pontos de venda era maior que o lote de produtos a ser entregue. Para os representantes da empresa, a disponibilização de outro caminhão para a coleta elevaria muito o custo da atividade, inviabilizando financeiramente o retorno das garrafas.

Ao pensar em alternativas, a empresa identificou outro desafio. O vidro é um material que perdeu atratividade para os catadores, uma vez que seu valor de mercado é baixo, em média cerca de $\mathrm{R} \$ 0,10$ o quilo, segundo dados do CEMPRE (2011). Também seu peso relativo é alto, dificultando o transporte, e apresenta riscos no manuseio, como cortes e perfurações. Assim, para viabilizar o fluxo reverso, era preciso pensar em uma forma que unisse uma coleta em grande quantidade com custos adequados. A parceria com a Vira-Lata conseguiu assegurar esses dois objetivos. O programa de logística reversa recebeu o nome de Glass is Good, iniciando-se em novembro de 2010.

\section{Construindo o fluxo reverso}

A Diageo faz o cadastramento de clientes como bares, restaurantes e casas de show, que são convidados a participar do programa e disponibiliza equipamentos como, por exemplo, máquina de triturar. A cada seis meses, a empresa informa e certifica o cliente com os resultados, visando conquistar clientes importantes e grandes geradores.

A cooperativa é responsável por coletar os materiais nas casas que foram cadastradas e gerar um relatório das quantidades coletadas mensalmente. Para melhorar a eficiência da coleta nos parceiros, a empresa organiza 
palestras para que tantos os proprietários como seus funcionários aprendam a separar os resíduos adequadamente. Isto é uma atividade fundamental, pois o programa envolve também como parceiro uma indústria de vidro que acaba fechando o ciclo. Essa empresa, além de fornecer o material para a Diageo, também compra o material recolhido do programa Glass is Good. Em contrapartida, exige que a cooperativa entregue o vidro limpo, sem contaminações e separado por cores, para que entre no processo produtivo.Os gráficos a seguir mostram a evolução da coleta de vidro e a receita gerada desde o início da parceria.

Gráfico 5

Volume de vidro coletado do Projeto Vira-Lata

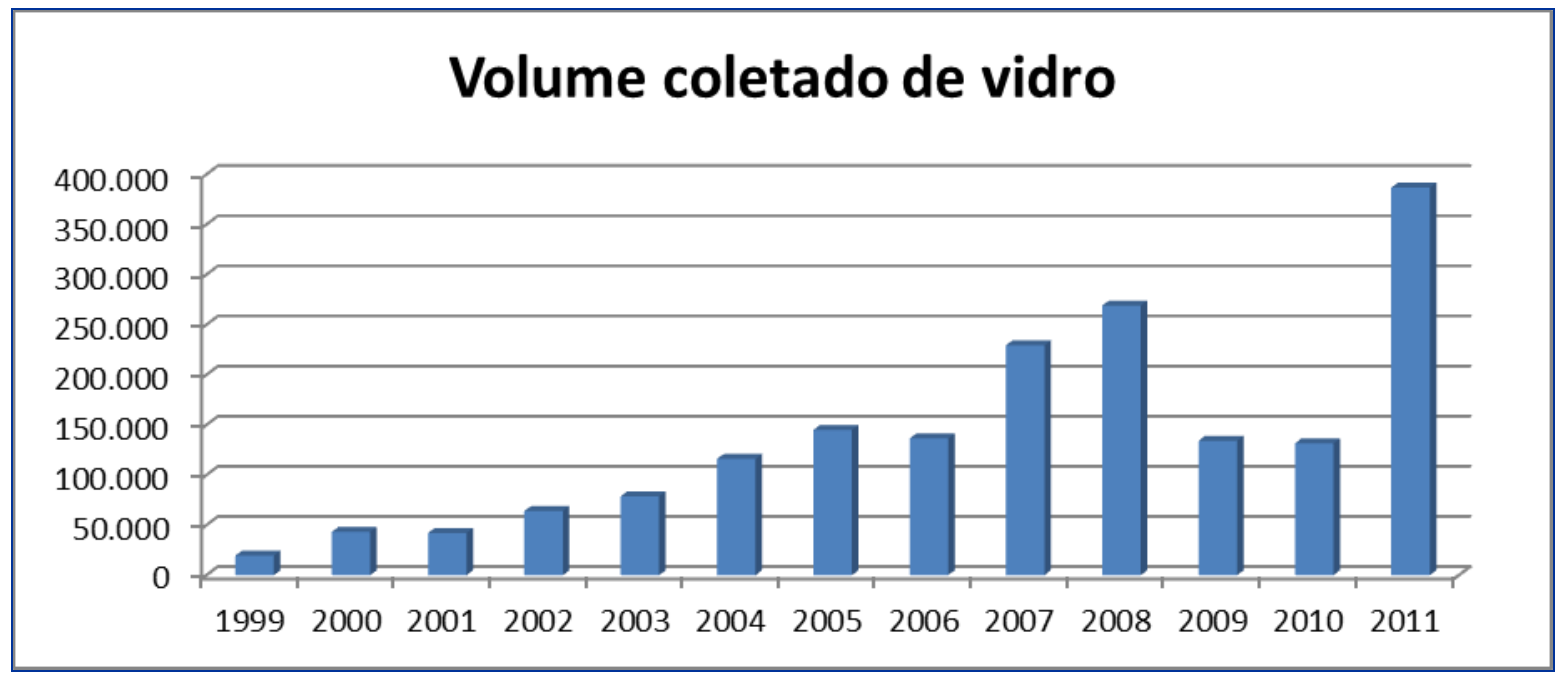

Fonte: Elaborado pelos autores (2012).

Gráfico 6

Receita gerada com a coleta de vidros

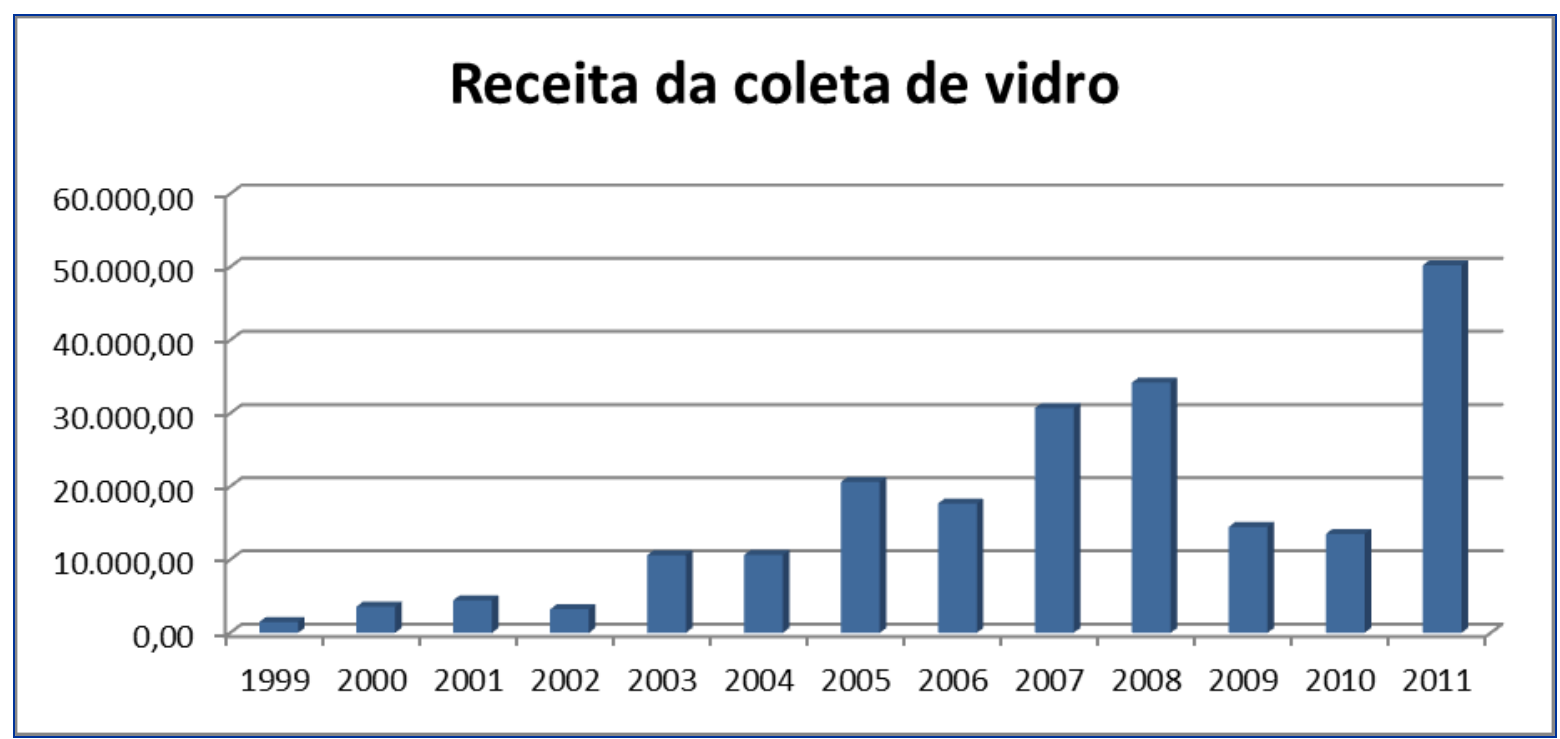

Fonte: Elaborado pelos autores (2012). 
Os gráficos mostram que o volume de material coletado e a receita gerada com vidro expandiram até 2008, quando atingiram seu auge, registrando 269 toneladas e uma receita de R \$ 34 mil. No entanto, esta evolução revela, já antes da crise, momentos de redução do volume coletado e da receita, ligados às dificuldades de comercialização do vidro já mencionadas. Com a crise, o baixo valor agregado tornaria a comercialização desse material ainda menos atrativa, resultando em diminuições expressivas do volume coletado. Em 2009, o total comercializado diminuiu $48 \%$ ou 140 toneladas e a receita $58 \%$ ou R \$ 14 mil. Em 2010, ao contrário do que ocorreu com a sucata, não se observa uma recuperação do volume e da receita. Houve inclusive uma diminuição de 6,4\% em relação a 2009, sendo coletadas apenas 131 toneladas de vidro.Os dados corroboram a ideia de que há um menor estímulo para trabalhar com o vidro, devido ao seu baixo valor agregado e às dificuldades de seu processamento. Uma análise mais focada no impacto da parceria com a Diageo, contudo, mostra o potencial para o reaproveitamento de materiais de baixo valor agregado quando se unem empresas e cooperativas de catadores.

Por meio da parceria com a Diageo, a Vira-Lata conseguiu coletar, de novembro a dezembro de 2010, 10 toneladas de vidro. Ou seja, em apenas um mês, a parceria gerou $8 \%$ de tudo que a cooperativa coletou durante o ano. Em entrevista realizada no início de 2011, somente no período de janeiro a fevereiro de 2011, esse número dobrou, alcançando 20 toneladas de vidro coletado. Com esses dados, a empresa estimava coletar 200 toneladas durante 2011. No entanto, uma nova visita à cooperativa em fevereiro de 2012 revelou que a estimativa anterior tinha sido amplamente superada, atingindo quase 387 toneladas, gerando uma receita de $\mathrm{R} \$ 50$ mil, correspondendo a $7 \%$ do faturamento anual da cooperativa.

Por fim, destaca-se que a integração entre a cooperativa de catadores e as empresas não deve ser analisada apenas pela renda e emprego gerados, e a viabilização de reaproveitamento de materiais recicláveis. Também é importante contabilizar os benefícios dessa atividade do ponto de vista ambiental. A Vira-Lata elaborou seu balanço ecológico com o apoio do Centro de Estudos de Apoio ao Desenvolvimento, Emprego e Cidadania (CEADEC) de Sorocaba, relativo à sua atuação no período de 1999 a 2008. Para chegar aos resultados finais, o CEADEC partiu de informações que mostram que a reciclagem de $1.000 \mathrm{~kg}$ de papel e papelão representa a economia de 17 árvores e uma redução de $20 \%$ do uso de energia elétrica em comparação com o processo produtivo tradicional. Já a reciclagem de $1.000 \mathrm{~kg}$ de vidro contribuiria com a economia de $1.200 \mathrm{~kg}$ de matéria-prima, incluindo areia, barrilha e calcário, 50 litros de óleo diesel e 60 litros de água. Assim, considerando, as quase 3,8 mil toneladas de papel, papelão e jornal recolhidas pela cooperativa no período, o CEADEC estimou uma economia de 63.905 árvores e quase 19 milhões de litros de água.

\section{Perspectivas para a Integração de Cooperativas nos Fluxos Reversos}

Com a aprovação da PNRS, abrem-se novas perspectivas para que a integração entre as empresas e os catadores organizados possibilite construir fluxos reversos mais eficientes e, ao mesmo tempo, colaborem para a transformação do cenário da cadeia de reciclagem brasileira. Porém, este objetivo esbarra em uma realidade em que as cooperativas enfrentam problemas organizacionais e operacionais para trabalhar diretamente com indústrias e empresas, que pouco conhecem a realidade das cooperativas. A partir das respostas para as questões apresentadas no início deste trabalho, a pesquisa procurou contribuir para o avanço deste debate, ainda pouco explorado na literatura.

Em primeiro lugar, essa pesquisa reforça as conclusões dos trabalhos anteriores que apontam o custo envolvido na atividade e o desinteresse das empresas em estruturar este processo como barreiras para a expansão da logística reversa (JAYARAMAN e LUO, 2007; STOCK e MULKI, 2009; LAU e WANG, 2009). A Porto Seguro e a Diageo não tinham interesse em montar um sistema próprio. Para a coordenadora do projeto da Diageo "ter transporte próprio dedicado à coleta encareceria o processo e não seria sustentável". Também a Gerdau, embora valorize o material disponibilizado pela Porto, não tem interesse em 
operar um sistema de coleta portaaporta. Nesse contexto, a cooperativa acabou viabilizando o fluxo reverso na medida em que realiza justamente as atividades que pouco interessam às empresas, tais como, coleta, transporte, armazenamento e comercialização, assumindo um papel de elo fundamental entre geradores de materiais recicláveis e recicladores. Dessa constatação, é importante aprofundar em que condições esta realidade se tornou possível.

Um elemento essencial neste processo, que reforça a argumentação de Lau e Wang (2009), e Lundgreen (2012), é a necessidade de integrar empresas, poder público e outros atores nas atividades de logística reversa nos países em desenvolvimento. O caso analisado corrobora esta argumentação, na medida em que as parcerias da Cooperativa Vira-Lata com a Prefeitura, empresas do poder público e organizações não governamentais foram elementos essenciais para viabilizar a incorporação da organização nos fluxos reversos das empresas analisadas. A participação do programa da Prefeitura viabilizou a cessão de um espaço, considerado hoje um dos maiores centros de reciclagem da cidade de São Paulo, onde é possível processar grande quantidade de material e igualmente armazenar. Já as parcerias com empresas públicas, como a Petrobras e a Fundação Banco do Brasil, garantiram recursos para investimentos em equipamentos como caminhões, prensas e trituradores que ampliaram a coleta e o pré-processamento de materiais. Nesse sentido, reforçaram os argumentos, também de Pereira e Teixeira (2011),sobre a importância da ampliação de recursos disponíveis para as cooperativas desde 2003. Além disso, a participação da cooperativa no programa da Prefeitura foi essencial, na medida em que a obrigatoriedade de ter documentos legais, como CNPJ entre outros, é inerente às parcerias envolvendo as cooperativas e o poder público. Uma das primeiras exigências das três empresas para as cooperativas de catadores se credenciarem como prestadoras de serviço é a apresentação de sua documentação legal. Nesse caso, vale ressaltar que as empresas estudadas defendem o trabalho conjunto com cooperativas como parte de suas políticas de responsabilidade socioambiental ao promoverem a inclusão social, geração de renda e diminuição de impactos ambientais em suas atividades. Porém, seu papel não é de garantir a formalização dessas organizações. Estão dispostas a apoiar com equipamentos e mesmo contribuir no aprimoramento da gestão administrativa a partir do momento em que as cooperativas atendam às exigências legais necessárias como fornecedoras. Outro aspecto importante para a profissionalização das cooperativas é a necessidade de produzir relatórios de controle de processos, incluindo volumes coletados e vendidos, assim como renda gerada. Ressalva-se que grande parte das cooperativas possui sistemas muito precários de controle de informações administrativo-financeiras. No caso da ViraLata, as informações são repassadas por exigência das empresas mensalmente, o que demanda a presença de cooperados com as habilidades necessárias para a elaboração dos relatórios. Nesse caso, este estudo também corrobora os argumentos de Jesus e Barbieri (2013), em que a integração das cooperativas nos fluxos reversos empresariais pode trazer também como benefícios um processo de aprendizagem para as cooperativas. O desenvolvimento de competências na sistematização de informações, por sua vez, abriu novas perspectivas para a organização comunicar seus stakeholders internos e externos, no que diz respeito à contribuição ambiental de suas atividades, com a elaboração de seu Balanço Ecológico.

Quanto ao terceiro questionamento sobre os benefícios diretos para a cooperativa de inserir no fluxo reverso, fazendo a ligação entre geradores e recicladores, os resultados são bastante promissores. Os resíduos de alto valor agregado gerados pelas empresas e doados à cooperativa são vendidos diretamente à indústria, eliminando os intermediários e elevando a receita dessas organizações, tornando a distribuição do valor gerado na cadeia de reciclagem mais justa.

É importante destacar que, embora a cooperativa analisada tenha sido profundamente afetada pela crise dos materiais recicláveis em 2009, sua inserção no fluxo reverso das empresas foi importante para amenizar tais impactos, na medida em que a variação dos preços da sucata ferrosa foi menor do que outros materiais. Isto reforça as conclusões de Aquino, Castilho Jr. e Pires(2009) sobre os benefícios de vender diretamente para a indústria.No caso analisado, talvez o mais surpreendente seja o resultado com a coleta de vidro. Diferentemente da sucata de ferro, que tem grande valor no mercado de recicláveis, o vidro deixou de ser um material de interesse para os catadores independentes e cooperativas. Trata-se de um resíduo de baixo valor agregado e grande peso, além de apresentar riscos em seu manuseio. No entanto, o caso mostra que quando 
trabalhado em grande quantidade e com garantia de venda direta para a indústria recicladora, esse material pode contribuir significativamente para gerar benefícios econômicos diretos para a cooperativa e, indiretamente,benefícios ambientais e sociais para a sociedade. Isto foi possível porque ao realizar o processo da logística, a cooperativa quebrou as barreiras para se inserir como fornecedora das indústrias recicladoras, conforme apontado por Gonçalves-Dias (2009). Grandes volumes de resíduos com qualidade e regularidade na entrega foram garantidos com o arranjo organizacional estudado. Chama a atenção os números registrados. Se em 2008, o vidro total coletado somava 269 toneladas, representando cerca de 4,6\% da receita,em 2011, somava 387 toneladas, representando 7,1\% da receita.Destaca-se ainda, segundo os entrevistados, que o valor do vidro recebido pela cooperativa é cerca de $80 \%$ maior do que se fosse vendido para organizações intermediárias. Interessante notar que o valor recebido pela cooperativa supera a média de preços recebida por outras cooperativas que também comercializam diretamente com as indústrias, que é de 40 a 60\%, conforme Jesus e Barbieri (2013). Infere-se que este resultado pode estar associado ao fato da Cooperativa Vira-Lata ter conseguido inserir-se em um fluxo reverso fechado. Ela coleta as garrafas dos bares e casas de show, clientes da Diageo, e vende o vidro pré-processado na forma de cacos, na qualidade requerida pela produtora de garrafas fornecedora da Diageo.

Um dado interessante também nessa análise é verificar a contribuição conjunta da sucata de ferro e do vidro para a receita total da Vira-Lata. Em 2006, quando nenhuma das empresas trabalhava com a organização, o total coletado de sucata e vidro contribuiu com cerca de 7\% da receita total. Em 2010, em um período em que os reflexos da crise ainda eram sentidos na cooperativa, sucata e vidro registraram $14 \%$ do total da receita auferida pela cooperativa. Já ao final de 2011, com a ampliação da coleta de sucata e vidro por meio da integração das empresas e da cooperativa, a contribuição para a receita total com a comercialização desses materiaiss atingiu $20 \%$.

Assim, infere-se que as parcerias não se limitam a assegurar preços melhores quando o mercado está aquecido, uma vez que também contribuem para diminuir a vulnerabilidade dessas organizações quando os preços pagos se reduzem. $\mathrm{O}$ caso apresentado é exemplar, pois indica a potencialidade dessas parcerias em conciliar interesses e gerar benefícios econômicos, sociais e ambientais. Do ponto de vista socioeconômico, trata-se de aumentar o volume de reuso de materiais recicláveis, gerando maior renda e trabalho digno para os que vivem hoje da coleta e da venda de materiais recicláveis nas cooperativas. Os benefícios ambientais aparecem na medida em que a reciclagem poupa os recursos naturais, associados à produção de matéria virgem, reduzindo a poluição do ar e da água. É importante destacar também os benefícios concretos gerados para as empresas. $\mathrm{O}$ arranjo promovido resultou em um sistema de coleta e destinação eficiente a um custo menor, caso todo o processo fosse coordenado exclusivamente pelas empresas estudadas. Além disso, as parcerias resultaram em outra contribuição concreta para as empresas ao evitar que suas garrafas cheguem ao mercado de bebidas falsificadas ou que as sucatas cheguem ao mercado paralelo de autopeças. Também as empresas defendem que mesmo sem um retorno financeiro direto para as empresas com esta iniciativa, "há vantagens intangíveis pela ação de responsabilidade social e ambiental, que revertem em benefício da marca".

Mesmo com todos os benefícios identificados, há desafios a serem superados para que iniciativas como estas se multipliquem no país. Para as cooperativas, há o desafio da profissionalização de seus processos, apontado por Ribeiro, Jacobi, Besen et al. (2009)e Jesus e Barbieri (2013),de forma a se qualificarem como fornecedoras das empresas, incluindo além da ampliação da infraestrutura, a regularização e o desenvolvimento dos sistemas de gestão das informações. No caso da Vira-Lata, esses desafios puderam ser mais facilmente superados em razão das parcerias estabelecidas anteriormente com o poder público e as organizações não governamentais. Dessa forma, quando se iniciaram as negociações entre as empresas e a cooperativa, esta última já contava com equipamentos, um sistema de acompanhamento de informações e regularização legal, exigidos pela parceria com a Prefeitura. Já para as empresas, identificaram-se também desafios e aprendizados importantes em relação ao engajamento dos fornecedores. No caso da Diageo, a simples promoção da coleta de vidros não significou uma adesão automática de bares e casas de shows ao programa. Uma ação de comunicação e estímulo à participação foi necessária, resultando na grande expansão 
da coleta em 2011, praticamente dobrando a meta estipulada pela empresa para o ano. Assim, reforça-se o argumento do trabalho de Jesus e Barbieri (2013) de que as organizações focais da cadeia de suprimentos, como no caso das empresas de bens de consumo, são essenciais para apoiar as cooperativas a desenvolverem fornecedores, ampliando a quantidade do material disponível para processamento. Percebeu-se, também, que a aproximação desses fornecedores com as cooperativas, ao entenderem melhor o que exatamente é o trabalho feito por estas organizações e como os resíduos encaminhados podem gerar emprego e renda, além dos benefícios ambientais da atividade, estimulou o maior engajamento dos funcionários na iniciativa.

\section{Conclusões}

O trabalho apresentado mostra que a cadeia de reciclagem brasileira consegue operar de forma eficiente dentro de uma lógica que preserva as relações desiguais entre os atores. No cenário atual, os catadores independentes, responsáveis pela maior parcela material processado na cadeia de reciclagem, são os que recebem a menor parcela do valor gerado na atividade. Além disso, mesmo no caso dos catadores organizados, há enormes desafios para a sustentabilidade das cooperativas. Problemas operacionais e de gestão dificultam a venda direta das organizações de catadores para a indústria. Já as empresas, que pouco conhecem sobre a realidade das cooperativas e as parcerias envolvendo esses dois atores, ainda são incipientes no Brasil. Com a aprovação da PNRS, abrem-se novas perspectivas para que estas parcerias se tornem uma realidade, fazendo com que os fluxos reversos sejam mais eficientes e, ao mesmo tempo, colaborem para uma transformação do cenário da cadeia de reciclagem.

As parcerias envolvendo empresas e catadores organizados em cooperativas podem contribuir para mudar este cenário, conforme o caso estudado. Vencendo as resistências das empresas em construir fluxos reversos pelos custos envolvidos ou ainda desinteresse em estruturar a atividade, as cooperativas podem garantir a coleta do material e seu beneficiamento a custos competitivos por possuírem o conhecimento necessário e, em alguns casos, contarem com a infraestrutura necessária para realizar a atividade, principalmente quando trabalham em parceria também com prefeituras e outras esferas do poder público. O caso estudado mostrou exatamente isso, a cooperativa se inseriu nas atividades de coleta e transporte que pouco interessa às empresas. Por sua vez, os resíduos de alto valor agregado gerados pelas empresas e doados à cooperativa são vendidos diretamente à indústria, eliminando todos os intermediários e elevando a receita dessas organizações. Esta comercialização direta mostrou que os benefícios também podem ser observados em épocas de crise no mercado de reciclagem, pois o preço recebido pela cooperativa com sucata apresentou uma variação significativamente menor do que os outros materiais comercializados.

A pesquisa também indica que a logística reversa exige das empresas um trabalho bem mais colaborativo e próximo das cooperativas do que as relações tradicionais de doação ou compra de material. Como argumentou um representante da Porto Seguro, há a necessidade do trabalho conjunto com a cooperativa para assegurar a qualidade do processo. Para ele, o trabalho com as cooperativas possibilita um "feedback de como os materiais estão saindo da empresa. Eles nos passam como está a qualidade do material e nós, internamente, desenvolvemos ações de reeducação ambiental". Além disso, como mostrou o caso da Diageo, o maior conhecimento da realidade da Vira-Lata possibilitou comunicar de forma mais efetiva a iniciativa, logrando um maior engajamento das organizações fornecedoras e seus funcionários, favorecendo um aumento significativo da coleta no ano de 2011.

Ao final deste trabalho, mesmo considerando os limites de um estudo de caso único, infere-se que a aproximação entre empresas e cooperativas possibilita que as organizações conciliemos interesses e potencializem os benefícios econômicos, ambientais e sociais, ao viabilizarem de forma mais eficiente a coleta, o transporte, a separação e a comercialização de resíduos pós-consumo. Espera-se que os resultados apresentados contribuam com insights para que os gestores das cooperativas, do setor privado e do poder 
público, desenvolvam novos arranjos na ótica da responsabilidade compartilhada, de forma a ampliar a logística reversa nos moldes propostos na PNRS. Salienta-se ainda que os trabalhos futuros devem incluir os seguintes temas de pesquisa:como viabilizar o pagamento dos serviços da cooperativa e a remuneração das atividades de coleta, separação e destinação; uma das principais bandeiras do MNCR continua sendo um elemento fundamental para a sustentabilidade das cooperativas. Na medida em que o valor das matériasprimas recicláveis é extremamente baixo, a viabilidade financeira das cooperativas é um grande desafio, mesmo com a doação de material, pois o custo com o transporte é muito elevado. Nesse contexto, uma questão igualmente importante para pesquisas futuras é a reformulação da atual estrutura tributária que não estimula o consumo de materiais recicláveis nos processos de manufatura. Incentivos físcais para a ampliação do consumo destes levaria a uma valorização da atividade de reciclagem, beneficiando as organizações que coletam e vendem materiais recicláveis. Também os incentivos fiscais poderiam contribuir para diminuir a resistência das empresas em investir em atividades de logística reversa. Por fim, sugere-se ampliar pesquisas de forma a confirmar o potencial da logística reversa em promover a continuidade das práticas de responsabilidade socioambiental das empresas em épocas de crise econômica. O MNCR (2012) argumenta que quando os preços de materiais virgens recuam, as empresas passam a privilegiar estes insumos, descontinuando suas relações com as cooperativas. Assim, seria importante verificar em outras iniciativas semelhantes, especialmente as que possibilitam o desenvolvimento de fluxos fechados, como no caso da embalagem de vidro relatada, se a logística reversa promove vínculos mais duradouros entre empresas e cooperativas, de forma que as soluções compartilhadas nos fluxos reversos contribuam efetivamente, nos países em desenvolvimento, para a construção de uma cadeia de reciclagem menos desigual.

\section{Referências}

AQUINO, I. F.; CASTILHO JR., A. B.; PIRES, T. S. L. A organização em rede dos catadores de materiais recicláveis na cadeia produtiva reversa de pós-consumo da região de grande Florianópolis: uma alternativa de agregação de valor. Gestão e Produção, v. 16, n. 1, p. 15-24, 2009.

BESEN; G. R. et al. Construção participativa de indicadores de sustentabilidade de coleta seletiva. In: ENCONTRO NACIONAL DOS PROGRAMAS DE PÓS-GRADUAÇÃO EM AMBIENTE E SOCIEDADE.V, 2013, Florianópolis. Anais...Florianópolis: ANPPAS, 2013.

CARVALHO, A. et al. Sustentabilidade na cadeia de suprimentos. In: VILELA JUNIOR, A.; DEMAJOROVIC, J. (Org). Modelos e Ferramentas de Gestão Ambiental: desafios e perspectivas para as organizações. São Paulo: Editora Senac, 2010. 401-429 p.

CEMPRE - COMPROMISSO EMPRESARIAL PARA A RECICLAGEM. Fichas técnicas, 2008. Disponível em: http://www.cempre.org.br/fichas_tecnicas.php?lnk=ft_pet.php. Acesso em: 22 jul. 2010.

DEMAJOROVIC, J. et al. Logística reversa: como as empresas comunicam o descarte de baterias e celulares? Revista de Administração de Empresas, v. 52, n. 2, p. 165-178, 2012.

; MATURANA, L. M. Desenvolvimento de produtos sustentáveis: purificadores de água Brastemp e carpetes Interface. Revista de Gestão Social e Ambiental, v. 3, n. 3, p. 102-119, 2009.

EIGENHAUER, E. M.; FERREIRA, J. A.; ADLER, R. R. Reciclagem: mito e realidade. Rio de Janeiro: In-Folio, 2005. 
EISENHARDT, K. M. Building theories from case studies. The Academy Management Review, v. 14, n. 4, p. 532550, out. 1989.

FLEISCHMANN, M. et al. A characterization of logistics network for product recovery. Omega - International Journal of Management Science, v. 28, n. 6, p. 653-666, 2000.

GERDAU. Faturamento da Gerdaucresce $\mathbf{1 8 \%}$ e alcança $\mathbf{R} \mathbf{\$} \quad \mathbf{3 5 , 7}$ bilhões. Disponível em: http://www.gerdau.com.br/media-center/noticias.aspx ?Codigo=87d71455-f6fe-4b56-94cc-

4c05884aa915\&language=pt-BR? Acesso em: 20 nov. 2012.

GIL, A. C. Projetos de pesquisa. São Paulo: Atlas, 1991.

GONÇALVES-DIAS, S. L. F. Catadores: uma perspectiva de sua inserção no campo da indústria de reciclagem, 2009. 296 f. (Doutorado em Ciências Ambientais). Programa de Pós-Graduação em Ciência Ambiental, Universidade de São Paulo.

GRINBERG, E. et al.Gestão sustentável de resíduos sólidos e inclusão social: estudo de caso sobre as cooperativas das centrais de triagem de coleta seletiva do Programa de Coleta Seletiva Solidária da Cidade de São Paulo.São Paulo: Instituto Polis, 2004.

GUNGOR, A. et al. Issues in environmental conscious manufacturing and product recovery: a survey. Computers \& Industrial Engineering, v. 36, n. 4, p. 811-853, 1999.

IJGOSSE, J. Women in informal employement: globalizing and organizing. In: SAMSON, M. (Ed). Refusing to be cast aside: waste pickers organizing around the world. Cambridge: Wiego, 2009.

INSTITUTO ETHOS DE EMPRESA E RESPONSABILIDADE SOCIAL. Vínculos sustentáveis em resíduos sólidos. 2007. Disponível em: http://www.ethos.org.br/_Uniethos/documents/VincSust_res_sold_A4.pdf. Acesso em: 10 jun. 2010.

JACOBI, P. et al. Gestão de resíduos sólidos em São Paulo:desafios da sustentabilidade. Estudos Avançados, v. 25, n. 75, p. 135-158, jan/abr. 2011.

JANSE, B. et al. A reverse logistics diagnostic tool: the case of the consumer electronics industry. The International Journal of Advanced Manufacturing Technology, v. 47, n. 5-8, p. 495-513, 2009.

JAYARAMAN, V. et al. Creating competitive advantages through new value creation: a reverse logistics perspective. Academy Management Perspective, v. 1, n. 2, p. 56-73, 2007.

JESUS, F. S. et al.Atuação das cooperativas de catadores de materiais recicláveis na logística reversa empresarial para reciclagem por meio da comercialização direta. In: ENCONTRO INTERNACIONAL SOBRE GESTÃO EMPRESARIAL E MEIO AMBIENTE, XV., 2013, São Paulo. Anais...São Paulo: ENGEMA, 2013. 01-15 p.

LAU, K. H. et al. Reverse logistics in the electronic industry of China: a case study. Supply Chain Management: An International Journal, v. 14, n. 6, p.447-465, 2009.

LUNDGREN, K. The global impact of e-waste: addressing the challenge International Labour Office, Programme on Safety. Geneva, 2012.

MNCR. Movimento Nacional dos Catadores de Materiais Recicláveis. In: JARDIN, A.; YOSHIDA, C.; FILHO, J. V. M. Politica Nacional e Gerenciamento de Resíduos Sólidos. SP: Manole, 2012. 
PEREIRA, M. C. G. et al. A inclusão de catadores em programas de coleta seletiva. Cad. EBAPE.BR, v. 9, n. 3, p. 895-913, 2011.

PORTO SEGURO. Demonstrações financeiras 2011. Disponível em: http://ri.portoseguro.com.br /portoseguro/web/arquivos/Publica\%E7\%E3o_Porto\%20SA\%202010.pdf. Acesso em: 20 nov. 2012.

RAVI, V. et al Selection of a reverse logistics project for end-of-life computers: ANP and goal programming approach. International Journal of Production Research, v. 26, n. 17, p. 4849-4870, 2008.

REVEILlEAU, A. C. Política Nacional de Resíduos Sólidos: aspectos da responsabilidade dos geradores na cadeia do ciclo de vida do produto. Revista Internacional de Direito e Cidadania, n. 10, p. 163-174, 2011. Disponível em: <www.reid.org.br/print/php/CONT=00000272.htm> Acesso em: 26 fev. 2012, $0031 \mathrm{~h}$.

RIBEIRO, H. et al.Coleta Seletiva com inclusão social. São Paulo: ANNABLUME, 2009.

ROGERS, D. S. et al. Going backwards: reverse logistics trends and practices. Reverse Logistics Executive Council. Reno: University of Nevada, 1998.

SOUZA, M. T. S.; PAULA, M. B.; SOUZA-PINTO, H. O papel das cooperativas nos canais reversos de pós-consumo. Revista de Administração de Empresas, v. 52, n. 2, p. 246-262, 2012.

STOCK, J. et al. Product returns processing: an examination of practices of manufacturers, wholesalers, distributors and retailers. Journal of Business Logistics, v. 30, n. 1, p. 33-62, 2009.

THIERRY, M. et al. Strategic issues in product recovery management. Management Review, v. 37, n. 2, p. 114-135, jan. 1995.

YIN, R. K. Estudo de caso: planejamento e métodos. 2. ed. Porto Alegre: Bookman, 2005. 